\title{
The Need for Effective Climate Justice to Protect the Environment
}

\section{Spada Jimenez A*}

Professor of criminal and civil proceedings, University of Malaga, Spain

*Corresponding author: Andrea Spada Jimenez, PhD in Law, Professor of criminal and civil proceedings, University of Malaga, Spain, Email: andrea.spada.j@hotmail.com

\section{Editorial}

Volume 4 Issue 3

Received Date: August 27, 2021

Published Date: September 22, 2021

DOI: $10.23880 /$ abca- 16000200

\section{Editorial}

It is evident that globalization has brought immense advantages to international society, mainly economic, which have increased the development of the economic market, the cultural progress of society and the systems of international cooperation with great material efficiency, and it is thanks to all this that the international community progresses as a whole.

The other side of globalization, however, is that which confronts us with a legislative and judicial system that advances at too slow a pace and even goes unnoticed when human rights are affected in favor of economic development. It is a system with a framework tailored to the economic and political interests of States and large transnational corporations that has led us to the current situation in which the very survival of human beings is at stake due to climate change.

We must start from the premise that climate change and human rights are inextricably linked. Climate change affects the right to life, health, food, water, sanitation, children's rights, peace, security and development. Hence, the solution must not only be based on the scientific level, but must also involve society and regulatory systems.

The increase in temperature has accelerated in recent years, with the highest temperatures ever recorded since data began to be collected. The heat in the atmosphere and in the sea is increasing, which has produced droughts and floods that have led to the loss of fertile land, water, crops and livestock, producing desertification and food insecurity to such an extent that 1 in 9 people suffered from hunger in 2018.

In turn, the melting of ice, causes the rise in sea level that produces flooding, tidal change, migration of species, increased typhoons, hurricanes and stronger storms and in more areas of the planet have produced major catastrophes. All this has caused 6.7 million new displacements in the middle of 2019 alone. The estimate for 2050 is alarming; more than 150 billion people will be forced to move.

Forests have been degraded to such an extent that 6.5 million hectares disappear annually. The loss of flora and fauna species in the last forty years has increased by 58 percent. Fires in 2019 year have been devastating and have occurred in all parts of the planet, including Siberia and Alaska, areas that are not prone to fires. In Brazil's Amazon forest and Australia alone, more than 7 million hectares have been lost in 2019 in each.

The ocean is acidifying which means that absorbing part of the greenhouse gases that are emitted into the atmosphere and those used in the soil and reach the sea is producing an increase in its acidity and as a consequence the loss of marine species, from prairies, corals, mollusks and fish. Each of these circumstances has occurred because our system has lost the balance to maintain temperature levels adequate for the survival of the planet.

The causes of such a decline in nature are of anthropogenic origin. This massive and frenetic industrial development, clouded by economic profit, lacking in preventive and precautionary measures for the protection of the environment, is caused by transnational corporations and States that carry out overexploitation of agriculture and livestock, deforestation, soil change, pollution, waste trafficking, illegal logging, illegal fishing, unsustainable fishing, extractive activities, species trafficking. In short, the economic greed of transnational corporations and States.

Human activity is the driving force behind climate change and is manifested schematically, with activities carried out legally and others illegally, as follows: 
- By greenhouse gas emissions.

- Combustion of coal, oil and gas.

- Deforestation in tropical forests and land use change.

- Massive livestock development.

- The use of nitrogen fertilizers and fluorinated gases.

- Commission of crimes against the environment (wildlife, forestry, fishing, pollution).

Now, it could be said that the causes that cause it are intruded within the development of the economic and social activity of the human being, by the need to produce and consume and in the achievement of the exploitation of resources for economic purposes. However, the problem arises when the destruction of the planet is framed within a veil called "development".

Development is not cutting down forests without taking into account that they are the habitat of various species of flora and fauna, of communities whose lives depend on those resources, it is not carrying out mining and oil extraction in protected and unprotected areas without considering the environment, it is not taking waste from your own State to another State under a supposed waste management, it is not trawling and destroying the seabed, it is not overproducing food to meet surface standards or to consume more than necessary at the cost of destroying ecosystems, it is not dumping waste in the sea without control, it is not poaching animals, it is not trafficking in species, nor is it massive or illegal fishing.

Development is to carry out a whole productive activity through techniques that respect the environment, to obtain a better quality of life, which is achieved through a circular economy, which allows maintaining the balance between the economic and productive activity of the human being and the protection of natural resources, because the human being depends on them.

Based on this premise, the determining factors for human activities that hinder sustainable development, destroy the environment and have an impact on climate change are diverse. According to the study carried out by UNEP and GRID-Arendal, it is established that the motivating factors for environmental crimes are the following:

- Corruption at the national and local level.

- Lack of national legislation.

- Lack of effective methods to ensure compliance with national and international environmental regulations.

- National and international demand for the products that are the object of the crime, whether they are species of flora, fauna, natural resources such as timber or waste.

- Existing national and local conflicts.

- Organized criminal organizations at national and international level.
In turn, taking into account that the IPCC determines that in order to achieve sustainable development and maintain the temperature at $1.5^{\circ} \mathrm{C}$, a key factor is to strengthen international cooperation and emphasizes the need to strengthen local communities, civil society, the private sector and national and local governments. This justification leads us to the conclusion that the main cause of the commission of crimes against the environment is therefore the absence of an effective system of judicial responsibility that would have a dissuasive and preventive effect, both nationally and internationally.

The reason for this is the current lack of willingness on the part of state leaders themselves to prosecute such activities, since it makes it easier for them to obtain economic gains, whether public or private, preferring to reach commercial and political agreements. For which, heterocompositive and self-compositive systems of dispute resolutions have been created, but which focus on investment or trade and not on assessing environmental damage.

State powers do not take into account that what is at stake is the very survival of human beings, having shown them-selves to be incapable of protecting their natural resources, nor are they capable of looking beyond the economic consequences of their actions. However, as stated by the Human Rights Committee in 2018, "environmental degradation, climate change and unsustainable development are some of the most pressing and serious threats to the ability of present and future generations to enjoy the right to life", so a legal solution must be sought in this regard.

Therefore, it is essential to create a climate justice system. An effective procedural system that guarantees prevention, retribution and reparation, with the aim of curbing those situations that favor climate change, since despite observing that their repercussions transcend national borders and that they generate a social, economic and environmental impact, they ultimately affect human rights. In international legislation, there is no instrument with a specific protection system to protect the environment, except for the international auto-compositive environmental dispute settlement systems whose submission is optional.

Therefore, without binding legislation and without the cooperation of the States, the only existing solution is to fight climate change with the procedural and judicial weapons that we have at our disposal, which is why we consider that the application of universal jurisdiction as a system of extraterritorial jurisdiction is the most appropriate measure to adopt in the short term.

With the application of universal jurisdiction, not only would we act against the impunity of crimes against the 
environment, but we would also protect the human rights violated by polluting activities. It is also applicable in the short term because it is an already existing principle, while it would have a deterrent effect necessary for the fight against climate change, especially because in most States the liability of the legal person is included. It would therefore be an applicable procedural instrument for achieving the desired climate justice.
However, the best long-term solution lies in the creation of an International Tribunal specialized in the matter and with a system of criminal liability for both natural and legal persons, created on the basis of an international codification of crimes against the environment, considering them as international crimes, as in the proposals of eco-crimes and ecocide that are currently being put forward by various research groups. 